\title{
Time to look for evidence : Results-based approach to biodiversity conservation on farmland in Europe
}

\section{Herzon, I.}

2018-02

Herzon, I, Birge , T, Allen , B , Povellato , A , Vanni , F, Hart , K, Radley , G , Tucker , G , Keenleyside , C , Oppermann , R, Underwood , E, Poux , X, Beaufoy , G \& Prazan , J 2018 , ' Time to look for evidence : Results-based approach to biodiversity conservation on farmland in Europe ' , Land Use Policy , vol. 71 , pp. 347-354 . https://doi.org/10.1016/j.landusepol.2017.12.011

http://hdl.handle.net/10138/323531

https://doi.org/10.1016/j.landusepol.2017.12.011

cc_by_nc_nd

acceptedVersion

Downloaded from Helda, University of Helsinki institutional repository.

This is an electronic reprint of the original article.

This reprint may differ from the original in pagination and typographic detail.

Please cite the original version. 


\section{Time to look for evidence: Results-based approach to biodiversity conservation on farmland in Europe}

Article in Land Use Policy · January 2018

DOI: $10.1016 / j$. landusepol.2017.12.011

CITATIONS

0

14 authors, including:

\section{Irina Herzon}

University of Helsinki

38 PUBLICATIONS 1,466 CITATIONS

SEE PROFILE

\section{Andrea Povellato}

Council for Agricultural Research and Econo... 31 PUBLICATIONS 137 CITATIONS

SEE PROFILE
READS

171

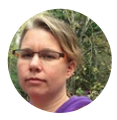

Traci Birge

University of Helsinki

12 PUBLICATIONS 28 CITATIONS

SEE PROFILE

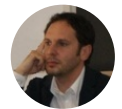

Francesco Vanni

CREA

44 PUBLICATIONS 76 CITATIONS

SEE PROFILE

Some of the authors of this publication are also working on these related projects: 
$1 \quad$ PROOF. To be published, with minor corrections, in Land Use Policy in early 2018

2 Time to look for evidence: results-based approach to biodiversity conservation on farmland in 3 Europe

4

5 Herzon $\mathrm{I}^{1}$, Birge, $\mathrm{T}^{1}$, Allen $\mathrm{B}^{2}$, Povellato $\mathrm{A}^{3}$, Vanni $\mathrm{F}^{3}$, Hart $\mathrm{K}^{2}$, Radley $\mathrm{G}^{4}$, Tucker $\mathrm{G}^{2}$, Keenleyside

$6 \mathrm{C}^{2}$, Oppermann $\mathrm{R}^{5}$, Underwood $\mathrm{E}^{2}$, Poux $\mathrm{X}^{6}$, Beaufoy $\mathrm{G}^{7}$, Pražan $\mathrm{J}^{8}$

$7 \quad{ }^{1}$ Department of Agricultural Sciences, P.O. Box 27, FI-00014 University of Helsinki, Finland

$8 *$ Corresponding author

9 2Institute for European Environmental Policy (IEEP), 11 Belgrave Road, IEEP Offices, Floor 3, 10 London SW1 V 1RB, United Kingdom

$11{ }^{3}$ Council for Agricultural Research and Economics, Centre for Policy and Bioeconomy (CREA-

${ }^{4}$ Independent environmental consultant Plum Tree House, Greatford, Stamford PE9 4QA, United

Kingdom

15 5nstitut für Agrarökologie und Biodiversität (IFAB), Böcklinstr. 27, D-68163 Mannheim, Germany

${ }^{6} \mathrm{AScA}, 8$ rue Legouvé 75010 Paris, France

${ }^{7}$ The European Forum on Nature Conservation and Pastoralism (EFNCP), Hamsterley Vale -

Derwentside 97, Durham, NE17 7BE, United Kingdom

${ }^{8}$ Institute of Agricultural Economics and Information Manesova 7512058 Praha 2 Czech Republic

\section{Abstract}

Increased use of annual payments to land managers for ecological outcomes indicates a growing interest in exploring the potential of this approach. In this viewpoint, we drew on the experiences of all schemes paying for biodiversity outcomes/results on agricultural land operating in the EU and EFTA countries with the aim of reviewing the decisive elements of the schemes' design and implementation as well as the challenges and opportunities of adopting a results-based approach. We analysed the characteristics of results-based schemes using evidence from peer-reviewed 
literature, technical reports, scheme practitioners and experts in agri-environment-climate policy. We developed a typology of the schemes and explored critical issues influencing the feasibility and performance of results-based schemes. The evidence to date shows that there are at least 11 advantages to the results-based approach not found in management-based schemes with similar objectives, dealing with environmental efficiency, farmers' participation and development of local biodiversity-based projects. Although results-based approaches have specific challenges at every stage of design and implementation, for many of these the existing schemes provide potential solutions. There is also some apprehension about trying a results-based approach in Mediterranean, central and eastern EU Member States. We conclude that there is clear potential to expand the approach in the European Union for the Rural Development programming period for 2021-2028. Nevertheless, evidence is needed about the approach's efficiency in delivering conservation outcomes in the long term, its additionality, impact on the knowledge and attitudes of land managers and society at large, development of ways of rewarding the achievement of actual results, as well as its potential for stimulating innovative grassroots solutions.

\section{Introduction}

In the words of McIntyre et al. (1992), the "struggle to maintain biodiversity is going to be won or lost in agricultural systems'. For terrestrial systems globally, agricultural expansion remains the most prominent threat, while in Europe, increased specialization and intensification, and abandonment of high nature value (HNV) farmland (Oppermann et al. 2012) threaten biodiversity on farmland (Stoate et al., 2009; Poláková et al. 2011). As a result, a particularly high proportion of semi-natural habitats, and associated species, that are dependent on HNV farming systems and are protected under the Habitats Directive have an unfavourable conservation status (EEA, 2015). Meaningful engagement of farmers remains the key to the fate of biodiversity in the long term (de Snoo et al. 2012).

In the European Union (EU), by far the largest source of funding for practical nature conservation is being delivered through the agri-environment-climate schemes (AES) implemented under the Common Agricultural Policy (CAP) (Poláková et al. 2011). A review of monitoring evidence suggests that most AES lead to biodiversity benefits, but the performance of some has been unsatisfactory (Batáry et al. 2015). The prescriptive nature of the AES, inflexible payment conditions, poor targeting, and a low priority put on actual results have been identified as some of 
61 the key reasons for poor effectiveness (Burton and Paragahawewa, 2011; Batáry et al. 2015). New

62 approaches to delivering biodiversity objectives on farmland that encourage farmers to actively engage with the goals of environmental management are needed alongside the existing ones. These include support to voluntary non-monetary activities (Santangeli et al. 2016) and making payments conditional on delivering ecological results (Zabel and Roe, 2009; Burton and Schwarz, 2013; Reed et al., 2014).

Making public or private payments conditional on the delivery of results, that is 'ecological goods and services', has been actively explored under the framework of payments for ecosystem services (Gerowitt et al., 2003). The possibilities for integrating the ecosystem services approach into AES have recently been emphasized, alongside discussion on the strengths and weaknesses of this type of approach (Meyer et al., 2016; Reed et al., 2014; Matzdorf and Meyer, 2014). The focus on outcomes that is implied in such payments makes the process of design and implementation reliant on adaptive management and the capacity of land managers for innovation. This, in turn, requires the development of multi-party governance systems and experiment-driven environmental policy (Hiedanpää and Borgström, 2014). Refining policy tools and delivery requires a cultural change in the way that farmers engage with policy on the ground involving, inter alia, clearer goals and results orientation (Buckwell et al., 2017). In their review Burton and Schwarz (2013), made a first attempt of synthesizing evidence from the result-oriented schemes (12 at a time) and focused at the cultural and social change these may promote and require. The situation in the field progressed rapidly since then.

In this viewpoint we focus on the results-based payment (RBP) approach applied specifically to biodiversity on agricultural land across Europe, including extensive livestock systems (e.g. reindeer herding in forest-tundra areas of Lapland) and other HNV farmland (e.g. traditional orchards). We present a typology of the existing schemes that remunerate land-managers, mostly farmers, for biodiversity outcomes in the EU and European Free Trade Association countries (Norway and Switzerland), explore critical issues influencing the feasibility of the approach in the design and implementation stages, and discuss the opportunities and challenges of the approach. The viewpoint largely draws on work commissioned by the European Commission to review the advantages and challenges of adopting the RBP approach for the protection and enhancement of biodiversity (for full report see Allen et al. 2014).

As part of the study, we analysed the characteristics of all RBP schemes operating in Europe (within and outside AES agreements) and 20 responses from questionnaires distributed to key 
practitioners involved in the design and implementation of these RBP schemes in 17 countries. Discussions with over 50 key experts in the field of agri-environment-climate policy and ecological indicators also aided the interpretation of the above evidence. Drawing from insights in the literature on participatory and experimental policy and on payments for ecosystem services, we discuss some of the opportunities and challenges of the RBP approach and suggest ideas for essential future research and policy development.

\section{Implementation of payment-by-results approach in Europe}

Though a multitude of schemes that involve payments for ecological services exist worldwide, there is no single agreed definition of what constitutes a 'results-based payment scheme' for biodiversity (other terms used are 'payment by results', 'outcome focused', 'performance payment', see Burton and Schwarz, 2013). We reviewed all schemes that, to varying degrees, financially reward or remunerate land managers for delivering verifiable biodiversity achievements on agricultural land. There is a range of approaches to delivering biodiversity objectives, from conventional management-based approaches to those that reward only the results irrespective of the management used. Despite the diversity of solutions, a pattern emerged relating to the extent to which the schemes' 'payment' and 'control' mechanisms are dependent on a priori specified biodiversity outcomes. Based on this pattern, we constructed a typology of the schemes (Table 1). At the time of the survey, there were only five schemes in Europe that paid according to the specified biodiversity results, prescribed no management interventions and allowed recipients of payments the complete flexibility to decide on management (i.e. pure results-based schemes, also Supplement Table A.1). Most of the RBP schemes were of the 'hybrid' type, in which certain management conditions were applied even if the payments were wholly dependent on results. We further discovered that the scheme type determines to a large extent specific implementation challenges and possible solutions.

\section{\#Table 1 here\#}

The first experiments with the RBP approach were carried out in the early 1990s using regional or national funding (Figure 1; Supplement Table A.1), and new schemes were introduced steadily in the following decades (Figure 1). Various national, regional, and provincial government sources, national park funds and private funding were used in the piloting stages, after which many of the 
schemes were integrated into CAP-funded agri-environment programmes (or the equivalent in Switzerland). These additional funding sources are still used in several cases. The majority of RBP schemes operate in Northern and Western European countries. Many schemes have been established as trials for specific localities. These focus on specific biodiversity objectives within the defined areas and, hence, the implementation scales remain relatively small in terms of area covered and number of farmers involved. Additionally, there are well-established schemes covering thousands of hectares and involving thousands of payment recipients (e.g., Suvantola, 2013; Zabel and Holm-Müller, 2008; Fleury et al., 2015; Russi et al. 2016). Several pilot projects or schemes have been discontinued or superseded by new approaches (for example, in The Netherlands, trial payments to farmers per clutch of meadow birds by Meadow Bird Agreements scheme for farmer collectives; Table A.1). In addition, a suite of new pilots is currently underway (Supplement Table A.1) in four countries.

Concurrently with the increase in the number of RBP schemes, there is a growing body of peerreviewed publications from research focused on the schemes (Figure 1). About half of them come from Germany, which has the highest number of federal government schemes and the longest experience with the approach. Most studies focus exclusively on the development and testing of ecological indicators and the schemes' performance in delivering ecological outcomes (e.g. Wittig et al., 2006; Bertke et al., 2008; Matzdorf et al. 2008; Höft et al. 2010; Kaiser et al, 2010). A handful of studies focus on the attitudes of recipients of payments to the new approach (e.g. Zabel and Holm-Müller, 2008; Schroeder et al. 2013), or on its economics (e.g. Hasund, 2013). In two countries research integrated ecological, social and economic assessments (e.g. Johst et al. 2002; Klimek et al. 2008; Haaren and Bathke, 2008; Magda et al. 2015; Russi et al., 2016). Valuable insights have been obtained from a re-assessment of the schemes' results and processes after decades of their implementation (Fleury et al., 2015; Russi et al., 2016).

\#Figure 1\#

The most common objective of the existing RBP schemes in Europe is the maintenance of seminatural grassland communities. There are also RBP schemes for traditional orchards and vineyards, as well as for animal species of EU and national conservation interest (e.g. protection of breeding birds from farming operations, and for threatened raptors and carnivores) (Supplement Table A.1). 
155 Numerous schemes offer headage payments for endangered native breeds of livestock, and area-

156 based payments for endangered native crop varieties. While such schemes are results-based in their design, they represent a distinct category of payment that we do not consider here. These and payments for the number of trees in traditional orchards in most German federal states are excluded from Figure 1.

\section{Ensuring effective design of results-based schemes}

Most of the issues that are critical to the design of a successful RBP are common to all schemes promoting environmental land management (Moxey and White, 2014). Among these are the skills and capacity of the authorities, administrative costs, the quality of the IT support systems, and attitudinal factors (e.g. Prager and Posthumus, 2010; Young et al., 2013). Differences lie in the particular skills and attitudes that are needed. Three issues appear to be particularly critical to the success of schemes that pay for results. These are: i) clearly defined environmental objectives, ii) suitable indicators of these objectives, on which the result payments are based, and iii) socioeconomic context.

The appropriateness of an RBP scheme will depend firstly on the definition of clear biodiversity objectives based on the most accurate and up-to-date data. Existing schemes mainly target the maintenance of threatened habitats (e.g. species-rich meadows) and species (e.g. Golden Eagle Aquila chrysaetos) rather than common farmland biodiversity (Supplement Table A.1) since their ecological requirements are well understood, as are the impacts on them of agricultural management. In general, RBP schemes are better suited to maintaining existing habitats that are in good ecological condition (where the farmers can draw on their experience in managing the habitat) rather than the restoration or re-creation of habitats (where conservation measures unfamiliar to the farmer may be required).

Secondly, there is a consensus that the existence of reliable indicators of the specified biodiversity objective is the most important practical consideration, since presence of the indicators is the basis for verification to release the payment. Burton and Schwarz (2013) argue that the success or failure of schemes in delivering their ecological results largely rests on the quality of the result indicators. In addition to the general criteria for a biodiversity indicator (e.g. Feest, 2013), the results indicators in RBP schemes on farmland should: i) not be easily achievable by means other than agricultural management, ii) be understandable and linked clearly to biodiversity objectives that are acceptable 
to land managers and paying agency representatives (i.e. not seen as 'bad farming'), and iii) be easily measurable following initial training (reviewed in Allen et al. (2014)). Designing an RBP scheme is justified only if potentially suitable biodiversity result indicators can be identified, which may not be possible for all biodiversity objectives or locations.

Thirdly, specific socio-economic factors need to be taken into account. These include stakeholder attitudes to innovation and risk taking, the existence of a culture of trust between the different actors, and accountability levels. Other important socio-economic factors, such as the capacity of the authorities and compatibility with other national policy regulations, are common to any payment scheme. Meyer et al. (2016) demonstrated that successful AES based on ecosystem service delivery require, above all, local-scale knowledge about economic, social, and ecological circumstances.

\#Box 1 here\#

We identified the essential steps for each stage of the life cycle of RBP approach (Box 1). At every stage, the approach has specific challenges for design and implementation and for many of these, the existing schemes provide potential solutions. Several questionnaire respondents in Greece, Estonia, Finland, Latvia, Slovakia and the UK perceived the RBP approach to be incompatible with the EU and/or WTO rules on calculating payments and their subsequent control and verification. This is contrary to the evidence (Hasund and Johansson, 2016; Russi et al., 2016): the payment level in most RBS schemes, like that of many management-based schemes, is determined in accordance with WTO rules. This means that the payment rate is calculated on the opportunity costs of the management that is considered most likely to be required to achieve the results, and not on a valuation of the results as such. RBP schemes are frequently built upon or complement existing AES and use the existing administrative infrastructure.

'Tuning' the scheme is best achieved during its piloting or over several years of scheme implementation (e.g. the process of gradual development of MEKA scheme in Germany in Russi et al., 2016; or the scheme for birds breeding in meadows in The Netherlands in Allen et al., 2014, p. 55, also Verhulst et al., 2007), which is true for any novel method of policy delivery (cf. Meyer et al., 2016; Radley, 2005). Options for indicators range from the numbers of a single species to a composite indicator with species numbers and habitat attributes (e.g. DAFF, 2016 in Ireland). The most important consideration is to ensure that the indicator thresholds do not reward the 
217 deterioration of the most biodiverse sites. This can be prevented by having multiple indicator 218 thresholds (as in Russi et al., 2016). In hybrid RBP schemes, the payments are dependent on some 219 management prescriptions that aim to maintain baseline conditions. Hybrid schemes may also be 220 required because not all biodiversity aims can be practically measured through indicators. However, 221 just as with the management-based payments, the owners of the sites with the highest biodiversity 222 may still not receive a sufficient incentive for maintaining exceptional biodiversity, if the threshold 223 is determined by the average situation.

224 Setting an appropriate payment level so that it reflects the full cost of achieving the desired 225 outcomes, including time spent on training and monitoring of ecological results by farmers, while 226 also keeping the schemes simple and cost-effective is a challenge (Cooper et al., 2009) that can be 227 resolved only through experimentation. The participation risk for newcomers to the scheme can be 228 reduced by setting fairly easy entry conditions with an increasing demand for a higher target and 229 higher payments later (Schroder et al., 2013). Ways of calculating payments vary from a single 230 bonus payment for the results additional to the baseline payment for management to an iterative 231 process of auctioning (see Allen et al., 2014 for the technical information). As with the 232 management-based AES payments, sustaining the participation level requires that remuneration 233 levels respond to the shifting opportunity costs of participating in the biodiversity scheme (Russi et 234 al., 2016). Practice shows that some AES, regardless of their nature, are not widely implemented if 235 the payment rates do not reflect the land managers' perceived costs, including time spent on the 236 application process and controls.

237 Ideally, the process of verifying result indicators should be such that the land managers can 238 understand and carry it out themselves. This is considered valuable regardless of whether the 239 managers are required to conduct their own verification of achieved ecological results, because it 240 allows assessment of one's performance and facilitates adaptive management (e.g. Fleury et al., 241 2015; Russi et al., 2016). Most farmers welcome a chance to learn more about the features they are 242 managing regardless of the payment structure (Fleury et al., 2015; Birge et al., 2017). Although 243 verification approaches vary among the schemes, the involvement of several interest groups 244 biologists, farmers or herders, agronomists, NGOs - in their development and testing is pinpointed as a basis for the scheme success (e.g., Fleury et al., 2015; Matzdorf et al., 2014). This can be 246 facilitated by involving voluntary organisations (e.g., environmental and community groups), which 247 can help fine-tune the scheme in line with principles of adaptive co-management as illustrated by 248 landscape stewardship initiatives in Europe (García-Martín et al., 2016). 
249 Attracting wider public attention to the innovative RBP schemes was an important part of 250 implementation in France and served as an additional reward instrument (Fleury et al., 2015). 251 Though it may not essential for the scheme's instigation, it may render long-term support in running 252 and enlarging the scheme. Regardless of their other attributes, all the schemes that were reviewed 253 demonstrated the need to keep things as simple as possible whilst achieving the desired biodiversity 254 outcome and recognising the needs of all the key interest groups.

\section{Opportunities and challenges}

257 Most of the potential advantages of the RBP approach for both the farmer and for the managing 258 authority compared to management-based schemes with similar objectives have been verified in the 259 literature (Table 2) and by experts. The majority of the respondents confirmed that uptake of the 260 RBP options has increased over time as land managers become more familiar with the new 261 approach (see also Burton and Schwarz, 2013). Some even considered the element of risk 262 associated with RBP schemes was mentioned as positive. Farmers can get a great sense of pride 263 from overcoming adversity, while management-based payments may not be engaging (e.g. an 264 interesting challenge) and are, instead, viewed as a bureaucratic nuisance (Sligo and Massey, 2007). 265 Integration of socio-economic co-benefits may increase uptake and promote long-term attitudinal 266 change (Burton and Paragahawewa, 2011): for example, in France, biodiversity aims are combined 267 with agronomic ones, which reinforces the production role of the farmer and results in a collective 268 learning process for all participants and increases public consensus on management objectives 269 (Magda et al., 2015; Fleury et al., 2015).

\#Table 2 here\#

We also identified circumstances where a well-designed and targeted management-based approach is likely to be more appropriate than a RBP one for the same environmental objective. Such situations particularly arise when: i) it is impossible to develop reliable indicators and methods of measuring them within reasonable costs, ii) achieving a measurable outcome takes an unreasonable length of time and delays the payment to the land manager (high concern for farmers), iii) the managing authority has no access to the information and expertise needed to set up and run a RBP scheme (high concern for authorities); or iv) the farming community is unwilling to accept a RBP 
approach. For example, there is a clear apprehension about initiating the RBP approach in Mediterranean, central and eastern EU Member States. The reasons mentioned were their recent predominant command-control culture and a lack of trust between the authorities and farmers (see also Prazan and Theesfelt, 2014). More clarity in the objectives behind the transactions between the state and farmer for the AES may be an important tool for building trust in the policy.

Devising an appropriate system for results verification has been cited as a critical difficulty in the adoption or extension of RBP schemes. While the high administrative costs of the RBP scheme in Ireland are regarded as a barrier to scaling up the scheme, Russi et al. (2016) provided evidence of low transaction costs and cost-efficient ways of verifying results in a long-running RBP scheme in Germany. Some costs of scheme establishment may be high in the early years and then decline (see also Schwarz et al., 2008). Competitive bidding for outcomes, as opposed to fixed-price payments, within the RBP approach may provide new opportunities in tackling over- and under-compensation for delivering the results (e.g. Klimek et al., 2008). However, in the set-up of tendering processes, a trade-off between the achievement of environmental outcomes and the budgetary costs usually leads the public agency to compromise solutions (Schilizzi and Latacz-Lohmann 2016).

It is not uncommon that management-based AES are designed to facilitate the reliable distribution of funds to farmers and to reduce running costs, with the major indicator of success being participation rates rather than actual environmental benefits (Keenleyside et al., 2011). This may be a "false economy" (Reed et al., 2014). Running costs may be lower, but there is a risk that the payments to farmers will not achieve any appreciable environmental benefit (Armsworth et al., 2012). Management based schemes may also have poor additionality: for example, continuing to provide payments to farmers even when the targeted outcome is no longer being achieved. Both approaches risk providing payments for outcomes that would have happened anyway with no added value to the existing situation (Russi et al. 2016). Unfortunately, little is known about the biodiversity cost-effectiveness of management-based AES, even if they have been running for decades.

In making payments dependent on the achievement of results, the RBP approach risks provoking disputes over whether or not those results have actually been achieved. A robust system of dispute resolution that is fair to both sides helps to increase farmers' confidence in the RBP schemes. In Ireland, farmers are not only given training in the assessment that determines payment levels but also are encouraged to challenge the scores given by the independent assessors (J. Moran, IT Sligo, pers. comm.). However, the close involvement of farmers may lead to the manipulation of baselines 
and thresholds on the land that may be enrolled in the scheme in ways that undermine environmental additionality (Zabel and Roe, 2009; Burton and Schwarz, 2013).

A major challenge faced by the RBP approach is, thus, enhancing the collaboration and trust among the parties, which would allow for fair and low-cost verification of the results, effective conflict resolution mechanisms, and experimentation with management for optimal delivery of results. Schemes that have been successful take full account of best practice in participatory policy processes. Effective involvement of payment recipient groups throughout the scheme's life cycle is essential for clear communication of the objectives as a precondition for payment, for risk management and conflict resolution (e.g., Stringer et al., 2006; Young et al., 2013; Reed et al., 2014). Bringing different types of knowledge together, framing situations for joint learning and planning in a collective manner, and engaging civil society organisations are all essential elements (Bruckmeier and Tovey, 2008; Meyer et al., 2016). Indeed, some of the RBP payments are made available as collective rewards (e.g. Zabel and Holm-Müller, 2008; de Lijster and Prager, 2012; Hiedanpää and Borgström, 2014). It is plausible that, in the future, the RBP approach will contribute to such socio-economic co-benefits as building community cohesion and multi-party networking around agricultural land-use.

Biodiversity outcomes are not the only area where the RBP approach could potentially be applied. This is demonstrated by payment schemes worldwide for such outcomes as water quality, soil protection, flood and fire resilience (Schomers and Matzdorf, 2013). For example, the AES aimed at water quality in German federal states include a results-oriented requirement (keeping $\mathrm{N}$ surplus below a specified level) (Techen and Osterburg, 2011; Wezel et al., 2016). A scheme in Spain aims primarily at reducing the fire hazards associated with publicly owned forestland (Ruiz-Mirazo et al., 2011). Each scheme targeted at an ecosystem service will have specific challenges of design and implementation.

\section{Conclusions}

Given the range of situations in which RBP schemes are appropriate, there is clearly considerable potential to expand the use of the approach within the AES for the next CAP Rural Development programming period 2021-2028. Addition of a results-based scheme as an alternative to or replacement for an existing management-based schemes aimed at the same biodiversity objective, or adding a more demanding results-based top-up to existing management-based scheme 
343 (contractually separate schemes) are relatively low-risk steps. However, when paying land 344 managers for the 'ecological goods and services' they provide, limiting compensation to covering 345 only the costs of production will remain a weak incentive, and does not reflect the risk involved. A true results-based approach should also reward the achievement of actual results, above the costs of their delivery, comparable to the profit margin of producing a market product (Reed et al., 2014). Practical solutions demonstrating how this principle can be implemented are still wanted.

A need to redefine the development path for EU farming past the 2020s by focusing CAP funding on delivering outcomes and maximising the cost-effectiveness of the policy has been identified by several authors (e.g. Mann, 2017). Any change in policy implementation carries a cost that can be recovered only with time. Examples from the existing schemes provide a variety of working solutions to many of the challenges of designing and implementing the RBP approach. These do, however, come from a limited number of countries. The recent support by the European Commission for piloting the RBP approach in four countries with contrasting socio-economic contexts and experience with the approach through targeted funding is well timed ${ }^{1}$. Equally important is intensification of research efforts on the aspects critical to the effectiveness of the approach. These are particularly: development of suitable indicators of the defined biodiversity objective, the additionality of the approach in the long-term delivery of biodiversity outcomes, cultural change, and, finally, cost efficiency and its change over time. Does the approach channel support to the conservation of the most important habitats and species and most important sites for them? Does it lead to enhancement of the existing biodiversity values over time compared to simply maintenance? Does it contribute to strengthening intrinsic motivations of participants? In what domains does the approach increase the awareness of farmers about the biodiversity on their land and their own role in its protection and production? And does this result in adaptive management and grassroots-level innovative solutions? Does it create links between farmers as providers of ecosystem services and the society as their consumer? How does cost efficiency develop with accumulated experience and widening implementation scales? How does cost efficiency of both results-based and management-based approaches for the same biodiversity objectives compare? Bridging sociological and ecological approaches will provide much needed monitoring of social cobenefits. Policy development for results-based approaches will also benefit from research into participatory modes and use of participatory modeling. In particular, focus on the process of social learning is necessary to orientate land managers and administration personnel alike toward results and experiment-driven environmental policy. The RBP schemes for biodiversity using the CAP and 
375 other tools make an important case for developing payments for ecosystem services in the European 376 context.

\section{Acknowledgements}

379 The authors are indebted to all interviewees and experts who shared their expertise, and reviewers.

380 The paper is based on the study, 'Biodiversity protection through results based remuneration of 381 ecological achievement', commissioned by the European Commission (ENV.B.2/ETU/2013/0046).

382 The full report and accompanying materials with detailed technical descriptions are available on 383 http://ec.europa.eu/environment/nature/rbaps/index_en.htm. IH and TB were supported by the Emil 384 Aaltonen Foundation, Finland.

385

${ }^{1}$ See the website rbaps.eu for further information

\section{References}

Allen, B., Hart, K., Radley, G., Tucker, G., Keenleyside, C., Oppermann, R., Underwood, E., Menadue, H., Poux, X., Beaufoy, G., Herzon, I., Povellato, A., Vanni, F., Pražan, J., Hudson, T., Yellachich, N. (2014) Biodiversity protection through results based remuneration of ecological achievement. Report Prepared for the European Commission, DG Environment. Institute for European Environmental Policy, London. 167 pp.

Armsworth, P. R., Acs, S., Dalimer, M., Gaston, K. J., Hanley, N., Wilson, P. (2012) The cost of policy simplification in conservation incentive programs. Ecol Lett 15, 406-414.

Batáry, P., Dicks, L.V., Kleijn, D., Sutherland, W.J. (2015) The role of agri-environment schemes in conservation and environmental management. Conserv Biol 29,1006-1016.

Bertke, E., Klimek, S., Wittig, B., (2008) Developing result-orientated payment schemes for environmental services in grasslands: results from two case studies in North-western Germany. Biodiversity 9, 91-95. 
401 Birge, T., Toivonen, M., Kaljonen, M., Herzon, H. (2017) Probing the Grounds: developing a 402 payment-by-results agri-environment scheme in Finland. Land Use Policy 61, 302-315.

403 Bruckmeier, K., Tovey, H. (2008) Knowledge in sustainable rural development: from forms of 404 knowledge to knowledge processes. Sociologia Ruralis 48, 313-329.

405 Buckwell, A., Matthews, A., Baldock, D., Mathijs, E. (2017) CAP - Thinking Out of the Box: 406 Further modernisation of the CAP - why, what and how? RISE Foundation, Brussels. 80 p.

407 Burton, R.J.F., Paragahawewa, U. (2011) Creating culturally sustainable agri-environmental 408 schemes. J Rural Studies 27, 95-104.

409 Burton, R.J.F., Schwarz, G. (2013) Result-oriented agri-environmental schemes in Europe and their 410 potential for promoting behavioural change. Land Use Policy 30, 628-641.

411 Cooper, T., Hart, K., Baldock, D. (2009) The provision of public goods through agriculture in the 412 European Union. Report prepared for DG Agriculture and Rural Development, Contract No 30-CE413 0233091/00-28, Institute for European Environmental Policy: London.

414 DAFF (2010) Terms and Conditions of the Burren Farming Conservation Programme. Department 415 of Agriculture, Fisheries and Food, Ireland. Available from: http://www.agriculture.gov.ie [cached 416 copy accessed 27.2.2017]

417 de Lijster, E. and Prager, K. (2012) The use of indicators in agri-environmental management in the 418 Netherlands. LandscapePartner and The James Hutton Institute Report. 41 p.

419 EEA (2015) State of nature in the EU. Technical report No 2/2015. 178 pp.

420 http://www.eea.europa.eu/publications/state-of-nature-in-the-eu [accessed 27.2.2017]

421 Feest, A. (2013) The utility of the Streamlining European Biodiversity Indicators 2010 (SEBI 2010) 422 Ecol Indicat 28, 16-21.

423 Fleury, P., Seres, C., Dobremez, L., Nettier, B., Pauthenet, Y. (2015) "Flowering Meadows", a 424 result-oriented agri-environmental measure: Technical and value changes in favour of biodiversity. 425 Land Use Policy 46, 103-114. 
426 García-Martín, M., Bieling, C., Hart, A., Plieninger, T. (2016) Integrated landscape initiatives in 427 Europe: Multi-sector collaboration in multi-functional landscapes. Land Use Policy 58, 43-53.

428 Gerowitt, B., Isselstein, J., Marggraf, R. (2003) Rewards for ecological goods - requirements and 429 perspectives for agricultural land use. Agric Ecosyst Environ 98, 541-547.

430 Groth, M. (2009) The transferability and performance of payment-by-results biodiversity 431 conservation procurement auctions: empirical evidence from northernmost Germany. Working 432 Paper Series in Economics, University of Luneburg, http://www.uni433 lueneburg.de/fb2/vwl/papers/wp 119 Upload.pdf [accessed 27.2.2017]

434 Haaren, C., Bathke, M., 2008. Integrated landscape planning and remuneration of agri435 environmental services. Results of a case study in the Fuhrberg region of Germany. J Environ 436 Manage 89, 209-221.

437 Hasund, K., P. (2013) Indicator-based agri-environmental payments: A payment-by-result model 438 for public goods with a Swedish application. Land Use Policy 30, 223-233.

439 Hasund, K.P., Johansson, M. (2016) Paying for Environmental Results is WTO Compliant. 440 Agricultural Economics Society and European Associations of Agricultural Economists (EAAE). 441 EuroChoices 0(0), 1-6. DOI: 10.1111/1746-692X.12110

442 Hiedanpää, J., Borgström, S. (2014) Why do some institutional arrangements succeed? Voluntary 443 protection of forest biodiversity in Southwestern Finland and of the Golden Eagle in Finnish 444 Lapland. Nature Conserv 7, 29-50.

445 Höft, A., Müller, J., Gerowitt, B. (2010) Vegetation indicators for grazing activities on grassland to 446 be implemented in outcome-oriented agri-environmental payment schemes in North-East Germany. 447 Ecol Indicat 10, 719-726.

448 Johst, K., Drechsler, M., Wätzold, F. (2002) An ecologic-economic modelling procedure to design 449 effective and efficient compensation payments for the protection of species. Ecol Econ 41, 37-49.

450 Kaiser, T., Rohner, M-S., Matzdorf, B., Kiesel, J. (2010) Validation of grassland indicator species 451 selected for result-oriented agri-environmental schemes. Biodiv Conserv 19, 1297-1314. 
452 Keenleyside, C., Allen, B., Hart, K., Menadue, H., Stefanova, V., Prazan, J., Herzon, I., et al. (2011) 453 Delivering environmental benefits through entry level agri-environment schemes in the EU. Report 454 Prepared for DG Environment. Institute for European Environmental Policy, London.

455 Klimek, S., Richter gen Kemmermann, A., Steinmann, H-H., Freese, J., Isselstein, J. (2008)

456 Rewarding farmers for delivering vascular plant diversity in managed grasslands: A 457 transdisciplinary case-study approach. Biol Conserv 141, 2888-2897.

458 Magda, D., de St. Marie, C., Plantureux, S., Agreil, C., Amioud, B., Mestelan, P., Mihout, S. 2015. 459 Integrating agricultural and ecological goals into the management of species-rich grasslands_ 460 learning from the flowering meadows competition in France. Environ Manage 56, 1053-1064.

461 Mann, S. 2017. Towards Agricultural Policy 3.0 - an agenda for agricultural research. EuroChoices 462 0. DOI: 10.1111/1746-692X.12161.

463 Matzdorf, B., Lorenz, J. (2010) How cost-effective are result-oriented agri-environmental 464 measures? - An empirical analysis in Germany. Land Use Policy 27(2), 535-544.

465 Matzdorf, B., Kaiser, T., Rohner, M-S. (2008) Developing biodiversity indicators to design efficient 466 agri-environmental schemes for extensively used grassland. Ecol Indicat 8, 256-269.

467 Matzdorf, B., Meyer, C. (2014) The relevance of the ecosystem services framework for developed 468 countries' environmental policies: a comparative case study of the US and EU. Land Use Policy 38, $469509-521$.

470 Matzdorf, B., Biedermann, C., Meyer, C., Nicolaus, K., Sattler, C., Schomers, S. (2014) Paying for 471 Green? Successful examples of PES from Germany, the United Kingdom and the United States.

472 Müncheberg, 208 pages. Online resource: http://www.civiland-

473 zalf.org/download/PayingforGreen_PESinpractice.pdf (accessed 14.03.17).

474 McIntyre, S., Barrett, G.W., Kitching, R.L., Recher, H.F. (1992) Species triage - Seeing beyond 475 wounded rhinos. Conserv Biol 6, 604-606.

476 Meyer, C., Schomers, S., Matzdorf, B., Biedermann, C., Sattler, C. (2016) Civil society actors at the 477 nexus of the ecosystem services concept and agri-environmental policies. Land Use Policy 55, 352478356. 
479 Moxey, A., White, B. (2014) Result-oriented agri-environmental schemes in Europe: A comment. $480 \quad$ Land Use Policy 39, 397-399.

481 Musters, C.J.M., Kruk, M., De Graaf, H.J., Keurs, W.T. (2001) Breeding birds as a farm product. 482 Conserv Biol 15, 363-369.

483 Oppermann, R., Beaufoy, G., Jones, G. (2012) High Nature Value Farming in Europe. Ubstadt484 Weiher, 544 pages.

485 Osbeck, M., Schwarz, G., Morkvenas, Z. (2013) Dialogue on ecosystem services, payments and 486 outcome based approach. Background Brief. SEI Stockholm Environment Institute, http://www.sei487 international.org/mediamanager/documents/Publications/Air-land-water-resources/BC-2013-PES488 Background-Brief.pdf

489 Techen, A.K., Osterburg, B. (2011) Verifiability of result-oriented policy measures to reduce N 490 emissions from German agriculture. Paper Presented at the at the Nitrogen and Global Change 491 Science Conference, 12th April, 2011, Edinburgh.

492 Verhulst, J., Kleijn, D., Berendse, F., 2007. Direct and indirect effects of the most widely 493 implemented Dutch agri-environment schemes on breeding waders. J Appl Ecol, 44, 70-80

494 Poláková, J., Tucker, G. M., Hart, K., Dwyer, J., Rayment, M. (2011) Addressing biodiversity and 495 habitat preservation through Measures applied under the Common Agricultural Policy. Report 496 prepared for DG Agriculture and Rural Development, Contract No. 30-CE-0388497/00-44, Institute 497 for European Environmental Policy, London.

498 Prager, K., Posthumus, H. (2010) Socio-economic factors influencing farmers' adoption of soil 499 conservation practices in Europe. In: Napier, T. (Ed.) Human Dimensions of Soil and Water 500 Conservation. A Global Perspective. Nova Science, pp. 203-223.

501 Prazan, J., Theesfelt, I. (2014) The role of agri-environmental contracts in saving biodiversity in the 502 post-socialist Czech Republic. Intern J Commons 8, 1-25

503 Prince, H.E., Bunce, R.G.H., Jongman, R.H.G. (2012) Changes in the vegetation composition of 504 hay meadows between 1993 and 2009 in the Picos de Europa and implications for nature 505 conservation. J Nature Conserv 20, 162 -169. 
506 Radley, G. (2005) Evaluating agri-environment schemes in England. In: Evaluating agri507 environmental policies - design, practice and results pp 161-175. OECD, Paris.

508 Reed, M.S., Moxey, A., Prager, K., Hanley, N., Skates, J., Bonn, A., Evans, C.D., Glenk, K., 509 Thomson, K. (2014) Improving the link between payments and the provision of ecosystem services 510 in agri-environment schemes. Ecosyst Serv 9, 44-53.

511 Ruiz-Mirazo J., Robles A. B., González-Rebollar J. L. (2011) Two-year evaluation of fuelbreaks 512 grazed by livestock in the wildfire prevention program in Andalusia (Spain). Agric, Ecosyst 513 Environ 141, 13-22.

514 Russi, D., Margue, H., Oppermann, R., Keenleyside, C. (2016) Result-based agri-environment 515 measures: Market-based intruments, incentives or rewards? The case of Baden Württemberg. Land 516 Use Policy 54, 69-77.

517 De Sainte Marie, C. (2014) Rethinking agri-environmental schemes. A result-oriented approach to 518 the management of species-rich grasslands in France, J Environ Planning Manage 57, 704-719.

519 Santangeli, A., Arroyo, B., Dicks, L., Herzon, I., Kukkala, A., Sutherland, W. J., Moilanen, A. 520 (2016) Voluntary non-monetary approaches for implementing conservation. Biol Conserv 197, $521209-214$.

522 Schilizzi, S., Latacz-Lohmann, U. (2016). Incentivizing and Tendering Conservation Contracts: The 523 Trade-off between Participation and Effort Provision. Land Economics 92, 273-291.

524 Schroeder, L., Isselstein, J., Chaplin, S., Peel. S, (2013) Agri-environment schemes: Farmers’ 525 acceptance and perception of potential 'Payment by Results' in grassland-A case study in 526 England. Land use Policy 32, 134-144.

527 Schwarz, G., Moxey, A., McCracken, D., Huband, S., Cummins, R. (2008) An analysis of the 528 potential effectiveness of a Payment-by-Results approach to the delivery of environmental public 529 goods and services supplied by agrie-nvironment schemes. Report to the Land Use Policy Group, $530 \mathrm{UK}$.

531 Sligo, F., Massey, C. (2007) Risk, trust and knowledge networks in farmers' learning. J Rural 532 Studies 23, 270-282. 
533 de Snoo, G.R., Herzon, I, Staats, H., Burton, Rob J.F., Schindler, S., van Dijk, J., Lokhorst, A.M., 534 Bullock, J., Lobley, M., Wrbka, T., Schwarz, G., Musters, C.J.M. (2012) Towards Effective Nature 535 Conservation on Farmland: Making Farmers Matter. Conserv Lett 6, 66-72.

536 Stringer, L.C., Prell, C., Reed, M.S., Hubacek, K., Fraser, E.D.G., Dougill, A.J. (2006) Unpacking 537 'participation' in the adaptive management of socio-ecological systems: a critical review. Ecol. Soc. $53811,39$.

539 Stoate, C., Báldi, A., Beja, P., Boatman, N.D., Herzon, I., van Doorn, A., de Snoo, G.R., Rakosy, 540 L., Ramwell, C. (2009) Ecological impacts of early 21st century agricultural change in Europe - A 541 review. J. Environ Manage 91, 22-46.

542 Suvantola, L. (2013) The Golden Eagle compensation scheme in Finland. In: Klenke, R.A., Ring, I., 543 Kranz, A., Jepsen, N., Rauschmayer, F., Henle, K. (Eds) Human - Wildlife Conflicts in Europe. 544 Springer-Verlag, Berlin and Heidelberg, 201-214. doi: 10.1007/978-3-540-34789-7_10

545 Wezel, A., Zipfer, M., Aubry, C., Barataud, F., Heißenhuber, A. (2016) Result-oriented approaches 546 to the management of drinking water catchments in agricultural landscapes. J Environ Planning 547 Manage 59, 183-202.

548 Wittig, B., Richter gen Kemmermann, A., Zacharias, D. (2006) An indicator species approach for 549 result-orientated subsides of ecological services in grasslands - A study in Northwestern Germany. 550 Biol Conserv 133, 186-197.

551 Young, J.C., Jordan, A., Searle, K.R., Butler, A., Chapman, D.S., Simmons, P., Watt, A.D. (2013) 552 Does stakeholder involvement really benefit biodiversity conservation? Biol. Conserv 158, 359553370.

554 Zabel, A., Holm-Müller, K. (2008) Conservation performance payments for carnivore conservation 555 in Sweden. Conserv Biol 22, 247-251.

556 Zabel, A., Roe, B. (2009) Optimal design of pro-conservation incentives. Ecol Econ 69, 126-134.

557 Zabel, A., Bostedt, G., Engel, S. (2014) Performance Payments for Groups: The Case of Carnivore 558 Conservation in Northern Sweden. Environ Resource Econ. 59: 613-631. 
Table 1: Typology of the payment schemes for biodiversity on agricultural land in Europe. More specific information on all results-based schemes by type and country of implementation is in Supplement Table A.1.

\begin{tabular}{|c|c|c|c|c|}
\hline Scheme & Category & Main characteristics & Basis for payment & Example schemes \\
\hline
\end{tabular}

\begin{tabular}{|c|c|c|c|c|}
\hline \multirow{3}{*}{ 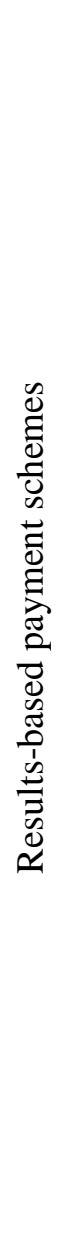 } & $\begin{array}{l}\text { Pure results- } \\
\text { based }\end{array}$ & $\begin{array}{l}\text { No management actions are } \\
\text { either specified or required }\end{array}$ & $\begin{array}{l}\text { Solely biodiversity results measured } \\
\text { with indicators: single payment } \\
\text { threshold, stepped payment thresholds } \\
\text { or continuously variable payments }\end{array}$ & $\begin{array}{l}\text { Species-rich grasslands in Brandenburg, } \\
\text { Germany: single payment for at least four } \\
\text { indicator plant species. Semi-natural } \\
\text { grassland in Lower Saxony, Germany: } \\
\text { payment for at least } 4 \text { indicator species and } \\
\text { top-up payment for additional } 2 \text { species. } \\
\text { Conservation performance payments in North } \\
\text { Sweden: payments according to the numbers } \\
\text { of wolverine and lynx offspring }\end{array}$ \\
\hline & $\begin{array}{l}\text { Hybrid: } \\
\text { Results-based } \\
\text { with baseline } \\
\text { management } \\
\text { requirements }\end{array}$ & $\begin{array}{l}\text { Holders have to undertake } \\
\text { some defined management } \\
\text { actions (or abstain from } \\
\text { certain activities) as a } \\
\text { baseline requirement of a } \\
\text { results-based contract }\end{array}$ & $\begin{array}{l}\text { Single or stepped payment thresholds } \\
\text { payment is wholly dependent on } \\
\text { biodiversity results, measured using } \\
\text { one or more environmental indicators; } \\
\text { management actions have to be } \\
\text { undertaken as an unpaid condition }\end{array}$ & $\begin{array}{l}\text { Species-rich grasslands in Baden- } \\
\text { Württemberg, Germany. Payment for at least } \\
4 \text { indicator plant species; additional } \\
\text { management requirements (e.g. no early } \\
\text { silage cuts). }\end{array}$ \\
\hline & $\begin{array}{l}\text { Hybrid: } \\
\text { Management- } \\
\text { based with an } \\
\text { optional }\end{array}$ & $\begin{array}{l}\text { Similar to the above but the } \\
\text { contract is management- } \\
\text { based and the results element } \\
\text { is optional }\end{array}$ & $\begin{array}{l}\text { Basic payment for management actions } \\
\text { and an extra (top-up) payment if } \\
\text { results are achieved }\end{array}$ & $\begin{array}{l}\text { Pasturing contracts in Solothurn, } \\
\text { Switzerland: basic payment for management } \\
\text { requirements, in addition several steps for } \\
\text { results based on judgement of species }\end{array}$ \\
\hline
\end{tabular}




\begin{tabular}{|c|c|c|c|c|}
\hline & $\begin{array}{l}\text { results-based } \\
\text { top-up }\end{array}$ & & & $\begin{array}{l}\text { richness, structural richness and difficulties } \\
\text { of management. }\end{array}$ \\
\hline 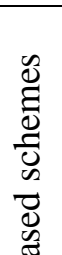 & $\begin{array}{l}\text { Management- } \\
\text { based schemes }\end{array}$ & $\begin{array}{l}\text { Holders only have to } \\
\text { undertake specified } \\
\text { management actions or } \\
\text { abstain from certain activities }\end{array}$ & $\begin{array}{l}\text { Payments linked to management } \\
\text { actions having the conservation of } \\
\text { biodiversity as their primary purpose }\end{array}$ & $\begin{array}{l}\text { Most of biodiversity schemes in AES } \\
\text { programmes }\end{array}$ \\
\hline 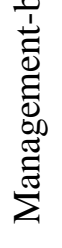 & $\begin{array}{l}\text { Farming } \\
\text { system } \\
\text { oriented } \\
\text { schemes }\end{array}$ & Same as above & $\begin{array}{l}\text { Payment linked to defined farming } \\
\text { systems known or believed to produce } \\
\text { biodiversity benefits. }\end{array}$ & $\begin{array}{l}\text { Schemes that promote organic farming or } \\
\text { seek to maintain High Nature Value Farming }\end{array}$ \\
\hline
\end{tabular}

562 
565 Box 1: Essential steps in the life cycle of the results-based payment scheme (after Allen et al., 566 2014).

\section{I Exploration and feasibility assessment}

1. Building sufficient scientific and expert knowledge of the influence of farming practices on species and ecosystems within the area of the proposed scheme.

2. Determining existence of biodiversity priorities, for which agricultural management is the key factor in ensuring the conservation of that biodiversity.

3. Checking compatibility of the RBP scheme with national policy regulations, especially for payments coming from the CAP.

4. Identifying potential sources of funding apart from the CAP.

\section{Design}

6. Setting a well-defined environmental objective that is sufficiently clear for land managers to understand and attractive to support (e.g. not conserving a noxious weed).

7. Choosing and testing appropriate and reliable indicators of the defined environmental objective.

8. 'Tuning' the scheme so that indicator thresholds are set at the right level to maintain or improve conservation condition, to encourage participation but prevent deterioration of the most biodiverse sites.

9. Designing an effective payment structure that is tailored to the biodiversity objectives and indicator thresholds, their ecological importance and desired uptake, and in compliance with the EU and national rules.

10. Developing a system of verifying results (not management) and controlling results-based payments that meet the EU requirements, and training the paying agency's staff in its use.

11. Developing an effective IT system that supports the design and operation of the scheme rather than distorting or limiting it.

12. Developing a simple, objective, repeatable and unambiguous method of monitoring whether the biodiversity indicators as well as expected biodiversity results have been achieved.

\section{Implementation stage}


13. Using an appropriate pilot to test out scheme design and operation, to give farmers practical experience of a results-based approach and to develop people with expertise in, and enthusiasm for, results-based schemes and who can train others and act as advocates for this approach.

14. Securing the positive engagement of land managers and other key stakeholders in scheme development, without diluting the environmental focus of the scheme.

15. Using the 'freedom to farm' that results-based schemes allow to build land managers' acceptance of, and interest in, environmental land management while providing guidance on management necessary to bring about the desired outcomes.

16. Providing high levels of facilitation, advice and support to applicants and contract holders.

17. Encouraging innovation, self-help and mutual learning, and finding positive ways of harnessing the power of peer group pressure.

18. Building up awareness about the scheme, also among the public.

\section{Evaluation and Review}

19. Monitoring, evaluating, and refining the RBP scheme based on learning from its implementation with engagement from all stakeholders. 
615 Table 2. The potential advantages of the results-based approach as compared to the conventional 616 management-based payment delivery based on literature and experts interviewed in the current 617 review.

Potential advantages

Clearer link between payment and biodiversity achievement and thus the transaction between the state and farmer

Effective achievement of an environmental objective that depends on a complex set of farm practices

Making the 'production' of biodiversity more an integral part of the farming system and farm business, not just another set of land management 'rules' to be followed

Giving farmers the opportunity to use their management skills, professional judgement and knowledge of the farm

Providing payment recipients with management flexibility for and to 'own' the biodiversity results More easily meeting the strengthened EU requirements for verification of AES payments under the 2014-2020 CAP Cutting 'deadweight' from schemes via a built-in incentive for farmers to select only the land where the biodiversity results are additional to the baseline

More straightforward verification and control

Operationalising the learning component of adaptive management for all actors: increasing the awareness of land managers about the biodiversity on their land, and contributing
Specific references

Matzdorf and Lorenz, 2010;

Zabel and Roe, 2009; Osbeck

et al., 2013

Matzdorf and Lorenz, 2010;

Prince et al., 2012

Matzdorf and Lorenz, 2010;

Burton and Schwarz, 2013;

Russi et al., 2016

Haaren and Bathke 2008;

Klimek et al., 2008; Osbeck et

al., 2013

De Sainte Marie, 2014;

Matzdorf and Lorenz, 2010;

Russi et al., 2016

Zabel and Holm-Müller, 2008;

Magda et al., 2015

Allen et al., 2014

Burton and Schwarz, 2013;

Birge et al., 2017

Matzdorf and Lorenz, 2010;

Groth, 2009; Russi et al., 2016

Magda et al., 2015; Fleury et

al., 2015; Russi et al., 2016 
to public recognition of farmers' role in supporting

biodiversity; changing farmer attitudes towards conservation

Creating or strengthening links among different actors
Haaren and Bathke 2008;

Zabel et al., 2014; Magda et al., 2015; Fleury et al., 2015 


\section{$619 \quad$ Figure legends}

620 Figure 1. Results-based payment schemes for biodiversity on agricultural land in Europe, number of 621 peer-reviewed publications that focus on specific results-based payment schemes (but not generally 622 describing the results-based approach) and the cumulative number of countries of the EU, Norway 623 and Switzerland with these schemes. The federal states in Germany are grouped together.

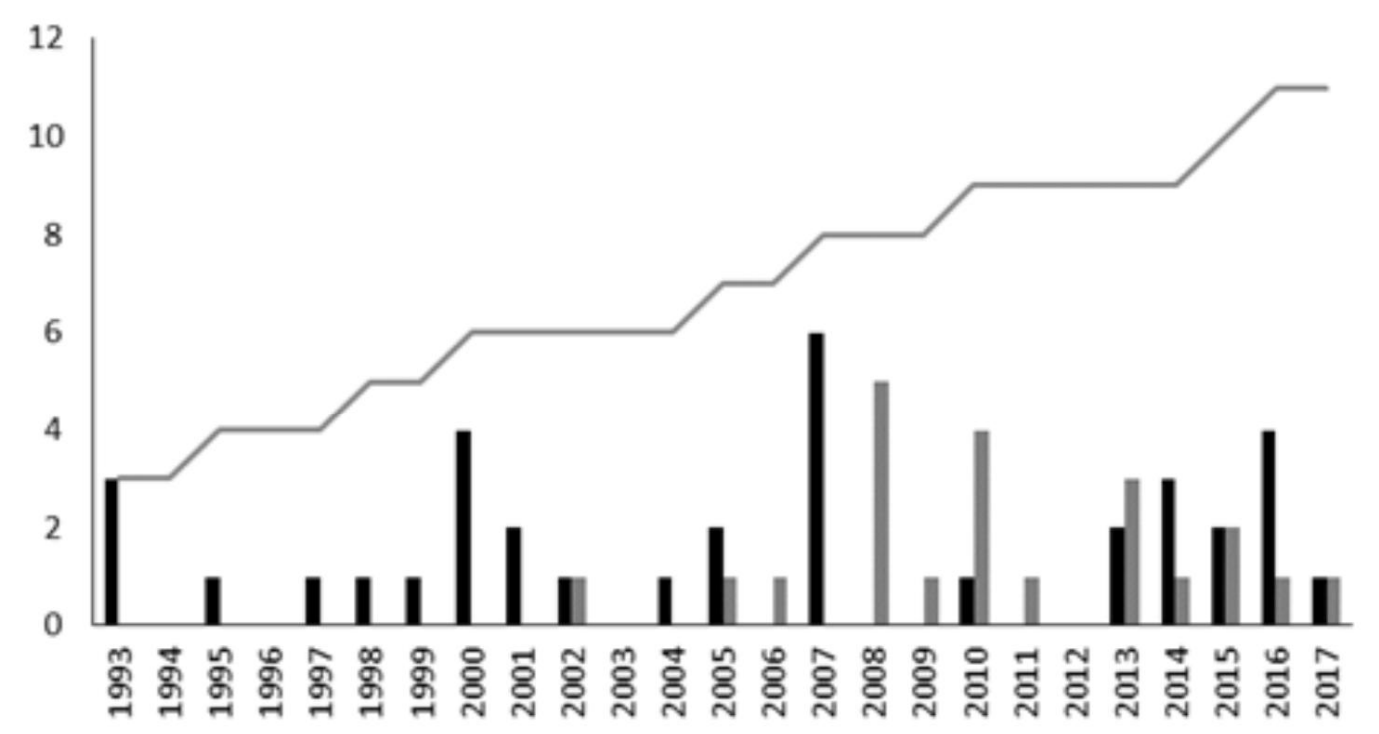


Appendix Table A.1. Existing and discontinued results-based payment schemes and their prototype assessments for biodiversity in agricultural environments in Europe, listed by country. Pure results-based and hybrid refer to the typology proposed here (Table 1). Description of most of the schemes' design can be found on the site Farming for Biodiversity: The results-based agri-environment-climate schemes (RBAPS- project) (last updated 10.06.2016) http://ec.europa.eu/environment/nature/rbaps/fiche/index_en.htm

\begin{tabular}{|c|c|c|c|c|c|}
\hline Country, region & $\begin{array}{l}\text { Startin } \\
\text { g year }\end{array}$ & $\begin{array}{l}\text { Name and/or biodiversity } \\
\text { objectives }\end{array}$ & Category & $\begin{array}{l}\text { Additional } \\
\text { information }\end{array}$ & Sources in English ${ }^{1}$ \\
\hline \multicolumn{6}{|c|}{ Existing or discontinued schemes } \\
\hline AT & 2015 & $\begin{array}{l}\text { Ergebnisorientierter } \\
\text { Naturschutzplan (ENP) } \\
\text { Semi-natural grazed } \\
\text { habitats }\end{array}$ & $\begin{array}{l}\text { Pure results- } \\
\text { based }\end{array}$ & & $\begin{array}{l}\text { RBAPS- project database } \\
\text { Results-based nature conservation plan - Pilot project } \\
\text { leaflet. Available at: http://static.suske.at. }\end{array}$ \\
\hline $\begin{array}{l}\text { FI Sami } \\
\text { Reindeer area }\end{array}$ & 1998 & Golden Eagle scheme & $\begin{array}{l}\text { Pure results- } \\
\text { based }\end{array}$ & $\begin{array}{l}\text { Collective } \\
\text { payments }\end{array}$ & $\begin{array}{l}\text { RBAPS- project database } \\
\text { Hiedanpää and Borgström, 2014; Suvantola, } 2013\end{array}$ \\
\hline FR & 2007 & $\begin{array}{l}\text { Flowering Meadows } \\
\text { Scheme (HERBE_07) } \\
\text { Species-rich grasslands }\end{array}$ & Hybrid & & $\begin{array}{l}\text { RBAPS- project database } \\
\text { Fleury et al., 2015; Magda et al., 2015; De Sainte Marie, } \\
2014 . \\
\text { RBAPS- site (includes a blog posting, video and conference } \\
\text { presentation) }\end{array}$ \\
\hline FR & 2007 & $\begin{array}{l}\text { Pastoral management plan } \\
\text { (HERBE_09) } \\
\text { Semi-natural grazed } \\
\text { habitats }\end{array}$ & Hybrid & & RBAPS- project database \\
\hline $\begin{array}{l}\text { DE Steinburg, } \\
\text { Schleswig- } \\
\text { Holstein }\end{array}$ & 2007 & $\begin{array}{l}\text { Blühendes Steinburg } \\
\text { Species-rich grassland }\end{array}$ & $\begin{array}{l}\text { Pure results- } \\
\text { based }\end{array}$ & $\begin{array}{l}\text { Privately } \\
\text { funded }\end{array}$ & RBAPS- project database \\
\hline
\end{tabular}


DE Baden-

Württemberg

DE Rheinland-

Pfalz

DE, other

federal states

DE, other

federal states

DE Nordrhein-

Westfalen

DE Bayern

DE, various

federal states
2000 MEKA B4

Species-rich grassland

2007 Kennarten programme (PAULa) (now EULL)

Species-rich grassland

2007 Species-rich grassland

schemes

Hybrid

Hybrid

Hybrid

2014 Species-rich grassland schemes

Hybrid

1993 Harrier nest protection in arable fields scheme

Hybrid

1999 Harrier nest protection in arable fields scheme

2007 German orchard schemes ( 8 schemes)
RBAPS- project database

Matzdorf, B. \& Lorenz, J. 2010; Russi et al., 2016.

RBAPS- project database.

RBAPS- site (includes a video).

RBAPS- project database

Schemes similar to those in Baden-Württemberg and

Rheinland-Pfalz were available in the agri-environmental programming period for 2007-2013:

- Niedersachsen \& Bremen,

- Rheinland-Pfalz,

- Thüringen

Bertke et al. 2008

RBAPS- project database

Schemes similar to those in Baden-Württemberg and Rheinland-Pfalz introduced to the agri-environmental programming period for 2014-2020 in:

- Bayern,

- Hessen,

- Sachsen

RBAPS- project database

Run by association Arbeitsgemeinschaft Biologischer

Umweltschutz im Kreis Soest e.V.

RBAPS- project database

Similar to Nordrhein-Westfalen scheme.

RBAPS- project database 
DE Bremen

2005 Grassland bird protection scheme

DE Schleswig-

Holstein

IE

NL

NL

NL per clutch trial scheme
1997 Grassland bird protection scheme

2010 Burren Farming for Conservation Programme
Hybrid

Hybrid

Hybrid

Hybrid Collective

payments

Pure results- Discontinued based

2000 Meadow Bird Agreements scheme
Schemes with per-tree payments for traditional orchards under the AES are available in most German federal states.

For example, in the period of 2007-2013:

- Bayern: Streuobst Anbau (KULAP A45);

- Brandenburg \& Berlin: A5, Pflege von Streuobstwiesen“;

- Nordrhein-Westfalen: Vertragsnaturschutz

Streuobstwiesenförderung (Paket 4301 und 4302;

- Rheinland-Pfalz: PAULa Vertragsnaturschutz Streuobst.

RBAPS- project database

Link to project website:

projekte/naturschutz/artenschutz/wiesenvogelschutz/

RBAPS- project database

RBAPS- site (includes a video).

Burren Programme http://burrenprogramme.com/

BurrenLIFE - Farming for conservation in the Burren

LIFE04 NAT/IE/000125

National Parks and Wildlife Service. Burren Life

Programme. https://www.npws.ie/research-projects/burren-

life-programme

RBAPS- project database

RBAPS-site (includes a video and conference presentation). de Lijster and Prager, 2012

RBAPS- project database

Musters et al., 2001; de Lijster and Prager, 2012; Verhulst et al., 2007; Kohler et al., 2007*

Changed in 2004 RBAPS- project database

and a new version de Lijster and Prager, 2012; The Netherlands 


\begin{tabular}{|c|c|c|c|}
\hline NL & 2000 & $\begin{array}{l}\text { Species-rich grassland } \\
\text { scheme }\end{array}$ & Hybrid \\
\hline ES Andalucía & 2005 & $\begin{array}{l}\text { RAPCA (Red de Áreas } \\
\text { Pasto Cortafuegos de } \\
\text { Andalucía), } \\
\text { pasture biodiversity }\end{array}$ & Hybrid \\
\hline $\begin{array}{l}\text { SE Sami } \\
\text { Reindeer area }\end{array}$ & 2000 & $\begin{array}{l}\text { Conservation performance } \\
\text { payments (Lynx \& } \\
\text { Wolverine) }\end{array}$ & $\begin{array}{l}\text { Pure re } \\
\text { based }\end{array}$ \\
\hline CH Solothurn & 1995 & $\begin{array}{l}\text { Pastures in Canton } \\
\text { Solothurn, }\end{array}$ & Hybrid \\
\hline $\mathrm{CH}$ & 2001 & $\begin{array}{l}\text { Species-rich grassland - } \\
\text { (Öko-Qualitätsverordnung, } \\
\text { ÖQV) }\end{array}$ & Hybrid \\
\hline $\mathrm{CH}$ & 2001 & $\begin{array}{l}\text { Rebflächen mit natürlicher } \\
\text { Artenvielfalt (ÖQV), } \\
\text { Species-rich vineyards in } \\
\text { Switzerland }\end{array}$ & Hybrid \\
\hline
\end{tabular}

introduced for the period 2016-2020.

Collective

payments

Changed in 2004

and a new version

introduced for the

period 2016-2020

Collective

payments

Pure results- Collective

payments

- project database

RBAPS- site (includes a video)

Zabel et al., 2014; Zabel and Roe, 2009; Zabel A and Holm-Müller, 2008

RBAPS- project database

Albrecht et al., 2007*; Knop et al., 2006*; Kohler et al., 2007*; Schwab et al., 2002*

As above

As above 
UK England, national park

\section{ES, Navarra \\ region \\ IE, County \\ Leitrim and \\ Shannon \\ Callows \\ counties \\ RO, Tarnava \\ Mare and the \\ Pogány \\ Havas/Muntii \\ Ciucului \\ regions \\ UK, England, \\ Wensleydale \\ and Norfolk/ \\ Suffolk}

DE

DE Northeim

(Niedersachse

n)
1993- Farm Conservation

Pure results-

1996 Scheme, species-rich hay based meadows

Pilots and prototype assessments

2016 Perennial crops of
vineyards, olive grove vineyards, olive groves and based almond groves

2016 Species-rich Grassland, Marsh Fritillary butterfly Habitat, Wet Grassland suitable for Breeding

Waders

2016 Hay meadows of high nature value

2017 Species rich hay meadow, Habitat for breeding waders, Winter bird food,

Pollen and nectar plants

2002 Prototype, White Stork (Ciconia ciconia) nests

2003- Prototype, arable weeds
Pure results-

Pure results-

based

Results-based

payment may be preceded by nonproductive

investments

Pure resultsbased

Farmers are offered guidance on the type of management that is most likely to achieve the results

Pure results-

based

Pure results-

based

Pure results- Auctioning based
Buckingham et al., 1998*; Schwarz and Morkvenas, 2012*

Project site: https://rbaps.eu/pilot-areas/navarraspain/mosaic-farmed-habitats-navarra/ (Last accessed 23.03.2017)

Project site: https://rbaps.eu/pilot-areas/rbaps-measures-inireland/ (Last accessed 23.03.2017)

Project site: https://rbaps.eu/rbaps-projects-romania-uk/

(Last accessed 23.03.2017)

Introduced into four existing agri-environment scheme options. Report available at https://www.gov.uk/government/publications/results-basedagri-environment-payment-scheme-rbaps-pilot-study-inengland (Last accessed 23.03.2017)

Johst et al., 2002.

Bertke et al., 2005*; Ulber et al., 2010*; Ulber et al., 2011. 
FI

SE

UK England
2015 Prototype, species-rich fallows

2013 Prototype, landscape

2013 Ex ante evaluation
Hybrid

Birge et al., 2017

Hasund, 2013

Schroeder et al., 2013

${ }^{1}$ If abbreviated, references are available in the Reference list of the main document or in the list below (marked with *). Sources in national languages in grey literature (e.g., reports and scheme documentation) are listed as Supplement Table A.2.

* Full references:

The Netherlands Environmental Assessment Agency (2007) Executive summary of the ecological evaluation of Nature Conservation Schemes run under the Stewardship Programme and the Dutch National Forest Service 2000-2006.

Kohler F, Verhulst J, Knop E, Herzog F and Kleijn D (2007) Indirect effects of grassland extensification schemes on pollinators in two contrasting European countries. Biol Conserv 135: 302-307

Albrecht M, Duelli P, Muller C, Kleijn D and Schmid B (2007) The Swiss agri-environment scheme enhances pollinator diversity and plant reproductive success in nearby intensively managed farmland. J Appl Ecol 44, 813- 822

Knop E, Kleijn D, Herzog F and Schmid B (2006) Effectiveness of the Swiss agri-environment scheme in promoting biodiversity. J Appl Ecol 43, 120-127

Kohler F, Verhulst J, Knop E, Herzog F and Kleijn D (2007) Indirect effects of grassland extensification schemes on pollinators in two contrasting European countries. Biol Conserv 135: 302-307

Schwab A, Dubois D, Fried P M and Edwards P J (2002) Estimating the biodiversity of hay meadows in north-eastern Switzerland on the basis of vegetation structure. Agric Ecosyst Environ 93, 197-209

Buckingham H, Chapman J and Newman R (1998) Meadows beyond the Millennium: The future for Hay Meadows in the Peak District National Park. 
Schwarz G and Morkvenas Z (2012) Review of outcome based agri-environmental payments and guidelines for the practical implementation of a pilot scheme in Lithuania. Baltic Compass project.

Bertke, E., Gerowitt, B., Hespelt, S. K., Isselstein, J., Marggraf, R., Tute, C. (2005) An outcome-based payment scheme for the promotion of biodiversity in the cultural landscape. In Lillak, R, Viiralt, R, Linke, A, Geherman, V (eds), Grassland Science in Europe: Integrating Efficient Grassland Farming and Biodiversity, pp 36-39. European Grassland Federation, http://www.europeangrassland.org/fileadmin/media/EGF2005_GSE_vol10.pdf\#page=53

Ulber, L, Klimek, S, Steinmann, H-H and Isselstein, J (2010) A market-based payment scheme for plant diversity in farming systems. Aspects of Applied Biology No 100 (Agri-environment schemes - what have they achieved and where do we go from here?), 319-326. 
Appendix A.2. Grey literature sources in national languages for the existing and discontinued results-based payment schemes for biodiversity in agricultural environments in Europe, listed by country.

Country and scheme(s)

Austria

Ergebnisorientierter

Naturschutzplan (ENP)

Semi-natural grazed habitats

France

Pastoral management plan

(HERBE_09)

Semi-natural grazed habitats

Germany

Blühendes Steinburg

Species-rich grassland
Sources in national languages

AgrarMarkt Austria https://www.ama.at/getattachment/84609631-6a37-4596-afe9-

f65572e7c50d/MEB_Oepul2015_Ergebnisorientierter_Naturschutzplan_3-0.pdf

Agreil, C., Barthel, S., Daneels, P., Greff, N., Guerin, G., Meignen, R., Mestelan, P. (2009). Étude pour

l'accompagnement de mesures agro-environnementales territorialisées combinant l'engagement unitaire Herbe_09 « Gestion pastorale ». Propositions méthodologiques à destination des opérateurs pour l'élaboration du plan de gestion pastorale.

Groth, M. (2008) Kosteneffizienter und effektiver Biodiversitätsschutz durch Ausschreibungen und eine ergebnisorientierte Honorierung: Das Modelprojekt „Blühendes Steinburg”. University of Lüneburg Working Paper Series in Economics No. 105.

Schleswig-Holstein MLUR (Ministerium für Energiewende, Landwirtschaft, Umwelt und Ländlichen Raum). 2014. Biotopkartierung.

Stiftung Naturschutz Schleswig-Holstein. 2014a. Blühendes Steinburg. Prämien für artenreiches Grünland - ein

Modellprojekt. Broschure.

Stiftung Naturschutz Schleswig-Holstein. 2014b. Blühendes Steinburg.

Voß, K. \& Jödicke, K. (2006) Erfolgsorientierte Honorierung ökologischer Leistungen im Grünland im Rahmen des Pilotprojektes 'Blühendes Steinburg'. Endbericht, Kiel. 
Germany

MEKA B4

Species-rich grassland
Briemle G. (2006) Ergebnisorientierte Honorierung von Extensivgrünland in Baden-Württemberg im Rahmen von MEKA II. Methode und Erfahrungen, 79-88. In: Hampicke, 2006. Anreiz: Ökonomie der Honorierung ökologischer Leistungen. Workshopreihe 'Naturschutz und Ökonomie' Teil I. BfN-Skripten 179. Bundesamt für Naturschutz.

Güthler, W. \& Oppermann, R. (2005) Agrarumweltprogramme und Vertragsnaturschutz weiter entwickeln. Mit der Landwirtschaft zu mehr Natur: Ergebnisse des F+E-Projektes. Heft 13, Bundesamt für Naturschutz, Bonn - Bad Godesberg. Institut für Ländliche Strukturforschung (IfLS) (2010) Halbzeitbewertung "Maßnahmen- und Entwicklungsplan Ländlicher Raum Baden-Württemberg 2007 - 2013 (MEPL II)“ nach der VO (EG) 1698/2005. Im Auftrag des Ministeriums für Ernährung und Ländlichen Raum Baden Württemberg, Stuttgart. Report 597 pp.

Krismann A., Dieterich, M., Oppermann, R. (2006) Evaluierung der Förderung ökologisch wertvollen Grünlands in MEKA II - Landesweite Untersuchungen 2002-2005. Endbericht 2005/2006.

MLR (2010) MEKA III - Ein Agrarumweltprogramm mit sichtbaren Erfolgen - Brochure on the whole agrienvironmental program in Baden-Württemberg.

MLR (2014) Kombinationstabelle MEKA III (flächenbezogene Teilmassnahmen) 2014.

Oppermann, R., Gujer, H.U. (2003) Artenreiches Grünland bewerten und fördern-MEKA und ÖQV in der Praxis (1). Verlag Eugen Ulmer, Stuttgart, Hohenheim.

Oppermann, R., Briemle, G. (2002) Blumenwiesen in der landwirtschaftlichen Förderung. Naturschutz und Landschaftsplanung 34, 203-209.

Oppermann, R. \& Krismann, A. (2002) Evaluierung der Förderung ökologisch wertvollen Grünlands in MEKA II Gutachten im Auftrag des Ministeriums für Ernährung und Ländlichen Raum, 162 S.; results partly published in Oppermann, R. \& Gujer, H. (Hrsg., 2003): Artenreiches Grünland. 
Germany

Kennarten programme (PAULa) Species-rich grassland
MLR (Ministerium für Ernährung und Ländlichen Raum). 2010. MEKA III - Ein Agrarumweltprogramm mit sichtbaren Erfolgen - Brochure on the whole agri-environmental program in Baden-Württemberg. MLR (Ministerium für Ernährung und Ländlichen Raum). 2014. Kombinationstabelle MEKA III (flächenbezogene Teilmassnahmen) 2014. Oppermann, R., Gujer, H.U., 2003. Artenreiches Grünland bewerten und fördern-MEKA und ÖQV in der Praxis (1). Verlag Eugen Ulmer, Stuttgart, Hohenheim.

Oppermann, R., Briemle, G., 2002. Blumenwiesen in der landwirtschaftlichen Förderung. Naturschutz und Landschaftsplanung 34, 203-209.

Oppermann, R. \& Krismann, A. 2002. Evaluierung der Förderung ökologisch wertvollen Grünlands in MEKA II Gutachten im Auftrag des Ministeriums für Ernährung und Ländlichen Raum, 162 S.; results partly published in Oppermann, R. \& Gujer, H. (Hrsg., 2003): Artenreiches Grünland.

DLR Rheinhessen-Nahe-Hunsrück. (2013) PAULa-Evaluierung - biotische Ergebnisse. Präsentation 14 März (2013) Fritz Mossel und Gunter Mattern, Landwirtschaft und Umwelt, Agrarumweltleistungen, DLR RNH Bad Kreuznach.

Horn, R., Simon, L., Ströger, L., Unkel, I. (2008) Rheinland-Pfalz - Entwicklung der neuen Kennartenprogramme zur erfolgsorientierten Honorierung von Grünland. Natur und Landschaft 5:206.

IfLS. (2010) Halbzeitbewertung Programm Agrarwirtschaft, Umweltmassnahmen, Landesentwicklung (PAUL) nach der VO (EG) 1698/2005. Bericht für das Ministerium für Wirtschaft, Landwirtschaft und Weinbau (MWVLW)

Rheinland-Pfalz. Institut für Ländliche Strukturforschung (IfLS).

LUWG (2011) PAULa Vertragsnaturschutz Grünland. Landesamt für Umwelt, Wasserwirtschaft und Gewerbeaufsicht des Landes Rheinland-Pfalz.

LUWG (2013) PAULa-Vertragsnaturschutzprogramm: Kennartenprogramme zur Grünlandförderung. Landesamt für Umwelt, Wasserwirtschaft und Gewerbeaufsicht des Landes Rheinland-Pfalz. 
Germany

Nordrhein-Westfalen

Harrier nest protection in arable

fields scheme

Germany

Nordrhein

Arable weeds

Germany

Bremen
LUWG (2010) PAULa-Vertragsnaturschutz Grünland. Kennarten. Landesamt für Umwelt, Wasserwirtschaft und

Gewerbeaufsicht.

MULEWF (2014) PAULa Grundsätze des Landes Rheinland-Pfalz für Vertragsnaturschutz Grünland - Kennarten.

Ministerium für Umwelt, Landwirtschaft, Ernährung, Weinbau und Forsten, Rheinland-Pfalz.

Rheinland-Pfalz. 2014. ELER Massnahmen.

ABU Soest (2013) Schutz von Rohr- und Wiesenweihen. Weihen Brutsaison 2013. Arbeitsgemeinschaft Biologischer

Umweltschutz im Kreis Soest e.V. Biologische Station Soest, Nordrhein Westfalen.

Bertke, E (2005) Ökologische Güter in einem ergebnisorienterten Honorierungssystem für ökologische Leistungen der Landwirtschaft: Herleitung - Definition - Kontrolle, PhD Thesis, University of Göttingen.

http://www.ibidemverlag.de/Unser-Verlagsprogramm/Oekologie---Landschaftspflege/Oekologische-Gueter-in-einemergebnisorientierten-Honorierungssystem-fuer-oekologische-Leistungen-der-Landwirtschaft.html

Höft, A (2012) Ableitung ergebnisorientert honorierbarer ökologischer Leistungen der Landwirtschaft am Beispiel einer Region in Nord-Ostdeutschland, Dissertation zur Erlangung des akademischen Grades Doktor der Agrarwissenschaften, Agrar- und Umweltwissenschaftliches Fakultät, Universität Rostock.

http://rosdok.uni-

rostock.de/file/rosdok_disshab_0000000811/rosdok_derivate_0000004869/Dissertation_Hoeft_2012.pdf

BUND Bremen (2014). Webpage: Wiesenvogelschutz. http://www.bund-

bremen.net/themen_und_projekte/naturschutz/artenschutz/wiesenvogelschutz/ 
Grassland bird protection

scheme

Germany

Schleswig-Holstein

Grassland bird protection

scheme
Jeromin, H. (2013) Wiesenvögel auf den Flächen des Pilotprojektes 'Grünlandwirtschaft Eider-Treene-Sorge' OrnithologischeUntersuchungsergebnisse 2013. UntersuchungimAuftrag der LokalenAktion Kuno e.V., NABU Michael-Otto-Institut, Schleswig-Holstein, Jeromin, H., \& Evers, A. (2013a) GemeinschaftlicherWiesenvogelschutz in Schleswig-Holstein 2013. Projektberichtfür das MinisteriumfürEnergiewende, Landwirtschaft, Umwelt und ländlicheRäume des Landes Schleswig-Holstein, NABU Michael-Otto-Institut.

Jeromin, H., \& Evers, A. (2013b) GemeinschaftlicherWiesenvogelschutz 2013 - Erprobung und WeiterentwicklungeinesArtenschutzprogramms. Projektberichtfür Kuno e.V., NABU Michael-Otto-Institut, SchleswigHolstein.

Kuno, e.V. (2014a) Artenschutzprogramm 'GemeinschaftlicherWiesenvogelschutz'. Infobroschüre.

Kuno, e.V. (2014b) Vertragsnaturschutzmuster "Grünlandwirtschaft Eider-Treene-Sorge".

Kuno e.V. (2014c) Gemeinschaftlicher Wiesenvogelschutz. Schleswig-Holstein.

Verein Kulturlandschaft nachhaltig organisieren (Kuno e.V.).

MELUR SH (MinisteriumfürEnergiewende, Landwirtschaft, Umwelt und ländlicheRäume des Landes SchleswigHolstein). (2014a) Natura 2000 - EuropäischeSchutzgebiete in der Flusslandschaft Eider-Treene-Sorge.

MELUR SH (MinisteriumfürEnergiewende, Landwirtschaft, Umwelt und ländlicheRäume des Landes SchleswigHolstein). (2014b) Vogelschutzgebiete. Beschreibung des Gebietes Eider-Treene-Sorge-Niederung.

MELUR SH (MinisteriumfürEnergiewende, Landwirtschaft, Umwelt und ländlicheRäume des Landes SchleswigHolstein). (2012a) Managementplan-Entwurffür das EuropäischeVogelschutzgebiet DE 1622-493 Eider-Treene-SorgeNiederungTeilgebiet 'Tetenhusen und Alt Bennebek'. 
The Netherlands

Breeding meadow birds - per clutch trial scheme

The Netherlands

Species-rich grassland scheme

Switzerland

Pastures in Canton Solothurn and Species-rich grassland (Öko-Qualitätsverordnung, ÖQV)
MELUR SH (MinisteriumfürEnergiewende, Landwirtschaft, Umwelt und LändlicheRäume des Landes SchleswigHolstein). (2012b) Management-planfür das EuropäischeVogelschutzgebiet DE 1622-493 Eider-Treene-SorgeNiederung und für das FFH-Gebiet DE 1622-391 Moore der Eider-Treene-Sorge-NiederungjeweilsTeilgebiet "NSG AlteSorge-Schleife".

Mugge, F. L.T., van Harmelene, W., Kruk, M. (1996) Natuurproduktie-betaling: een bruikbaar instrument voor het agrarisch natuurbeheer? Een evaluatie van de experimenten en een vergelijking met andere systemen van agrarisch weidevogel- en slootkantbeheer. Rijksuniversiteit Leiden, afdeling Milieubiologie.

van Paassen, A. G., Terwan P., Stoop, J. M. (1991) Resultaatbeloning in het agrarisch natuurbeheer. Centrum voor Landbouw en Milieu, Utrecht.

Schekkerman, H., Muskens, G (2000) Produceren Grutto's Limosa limosa in agrarisch grasland voldoende jongen voor een duurzame populatie? Limosa 73, 121-134.

Subsidieregeling Agrarisch Natuurbeheer - Bijlage 1: Beheerspakketten

Ministerie van Landbouw, Natuur en Voedselkwaliteit (2006) Plattelandsontwikkelingsprogramma, Nederland Bijlagen (RDP - Annexes)

Bundesamt für Umwelt (BAFU) (2014) Indicator Ecological Compensation Areas 1993- 2011.

Bundesamt für Landwirtschaft (BLW) (2013) Agrarbericht 2013. Bern, 328 pages.

Güthler W and Oppermann R (2005) Agrarumweltprogramme und Vertragsnaturschutz weiter entwickeln. Mit der Landwirtschaft zu mehr Natur: Ergebnisse des F+E-Projektes. Heft 13, Bundesamt für Naturschutz, Bonn - Bad Godesberg.

Herzog F, Walter T, Aviron S, Birrer S, Buholzer S, et al. (2005) Wirkung der ökologischen Ausgleichsflächen auf Biodiversität und Landschaft. Schriftenreihe FAL 56: 185-201. 
Rebflächen mit natürlicher Artenvielfalt (ÖQV), Speciesrich vineyards in Switzerland
Walter T, Eggenberg S, Gonseth Y, Fivaz F, Hedinger C, Hofer G, Klieber-Kühne A, Richner N, Schneider K, Szerencsits E and Wolf S (2013) Operationalisierung der Umweltziele Landwirtschaft. Bereich Ziel- und Leitarten, Lebensräume (OPAL) Forschungsanstalt Agroscope Reckenholz-Tänikon ART, ART-Schriftenreihe 18, 136. Bundesamt für Landwirtschaft BLW (2014) Weisungen nach Artikel 59 und Anhang 4 der Verordnung über die Direktzahlungen an die Landwirtschaft (Direktzahlungsverordnung, DZV) vom 23. Oktober 2013, SR 910.13 Rebflächen der Qualitätsstufe II mit natürlicher Artenvielfalt.

www.landwirtschaftsamt.tg.ch/documents/2014_Weisungen_2014_zum_Anhang4_der_DZV_Rebflaechen_der_Qualita etsstufeII_mit_natuerlicher_Artenvielfalt.pdf

Bundesamt für Landwirtschaft (BLW) (2013) Agrarbericht 2013. Bern, 328 pages.

www.blw.admin.ch/dokumentation/00018/00498/index.html 